\title{
FUNDUSZE SMART BETA - PASYWNE I EFEKTYWNE ZARZĄDZANIE PORTFELEM INWESTYCYJNYM
}

\section{WSTĘP}

Fundusze inwestycyjne są instytucjami finansowymi, których przedmiot prowadzonej działalności stanowi efektywne lokowanie środków pieniężnych uczestników, głównie na rynkach finansowych. Dominujacym modelem zarządzania powierzonym kapitałem jest podejście aktywne. Zakłada ono, że decyzje w zakresie alokacji aktywów i selekcji instrumentów finansowych podejmowane sa przez zarządzającego $\mathrm{w}$ ramach określonej w polityce inwestycyjnej funduszu swobody. Alternatywę dla podejścia aktywnego proponują fundusze inwestycyjne zarządzane w sposób pasywny, których strategia inwestycyjna opiera się na możliwie dokładnej replikacji zmian określonego indeksu rynkowego. Na skutek rozwoju technologicznego i pojawienia się nowych koncepcji teoretycznych w ramach tak zarysowanego podziału wyłoniła się trzecia kategoria funduszy określanych jako smart beta. Fundamentem ich funkcjonowania jest oparcie portfela inwestycyjnego na zachowaniu specjalnie opracowanego indeksu, którego konstrukcja ma zapewnić wyższą efektywność inwestycji niż ta wynikająca $\mathrm{z}$ inwestycji typowo pasywnej. Ponieważ ich zadaniem jest łączenie zdolności generowania ponadprzeciętnych stóp zwrotu z przejrzystą struktura i niskimi opłatami za zarządzanie, fundusze smart beta stanowią bardzo interesująca hybrydę klasycznych funduszy zarządzanych aktywnie i pasywnie.

Obietnica ponadprzeciętnych wyników w połączeniu z realizacją transparentnej strategii generującej niskie koszty skutecznie przyciaga uwagę zarówno inwestorów, jak i środowisk akademickich. Z jednej strony weryfikowana jest skuteczność tego typu rozwiązań w realizacji ich głównego celu inwestycyjnego, z drugiej - przedstawiane są nowe koncepcje zastosowania efektywnych strategii. Przy czym dotychczasowa uwaga badaczy ograniczała się głównie do Stanów Zjednoczonych. W przypadku rynku polskiego fundusze smart beta wciąż pozostają koncepcją szerzej nieznaną, co stanowiło przesłankę dla powstania niniejszego opracowania.

Struktura niniejszego artykułu zakłada jego podział na trzy części. W części pierwszej przedstawiono teoretyczne fundamenty powstania funduszy smart beta jako konsekwencji długofalowej ewolucji podejścia do zarządzania portfelem inwestycyjnym. Następnie zaprezentowano ogólną ideę funkcjonowania funduszy smart beta oraz nakreślono ich miejsce w strukturze segmen- 
tu rynku finansowego, którym są instytucje wspólnego inwestowania. Artykuł zamyka jego główna i najobszerniejsza część - pogłębiony przegląd kluczowych aspektów technicznych związanych z budową efektywnie działającej strategii wykorzystywanych przez fundusze smart beta przeprowadzony na podstawie studiów literaturowych.

\section{EWOLUCJA PODEJŚCIA DO ZARZĄDZANIA PORTFELEM INWESTYCYJNYM W KONTEKŚCIE ROZWOJU SPOSOBU POMIARU EFEKTYWNOŚCI INWESTYCJI}

Obowiązujące mniej więcej do lat pięćdziesiątych ubiegłego wieku modele opisujace funkcjonowanie rynku finansowego zakładały, że decyzje inwestorów determinowane są dążeniem do maksymalizacji bieżącej wartości dochodów na skutek przyrostu wartości utrzymywanych instrumentów finansowych. Wskazania teorii wcielały w życie ówczesne podmioty zarządzające aktywami, które za główny cel prowadzonej działalności obierały maksymalizację stopy zwrotu z portfela inwestycyjnego, zwykle złożonego z wielu instrumentów finansowych ${ }^{1}$ (większość tradycyjnych portfeli skoncentrowana była na akcjach).

Warto zwrócić uwagę na sprzeczność takiego podejścia: aby maksymalizować zysk z inwestycji, należałoby całość środków zgromadzonych w ramach portfela ulokować $\mathrm{w}$ jednym instrumencie charakteryzującym się najwyższa wartością stopy zwrotu. Natomiast konstruując portfel wieloelementowy - zarządzający zaniżali jego oczekiwaną dochodowość przez utrzymywanie mniej zyskownych instrumentów finansowych. Paradoks ten zaobserwował Harry Markowitz ${ }^{2}$, czyniąc z niego fundament swojej autorskiej koncepcji modelu rynku finansowego, który nazwano nowoczesną teoria portfela (modern portfolio theory). Przełomowe było wprowadzenie do analizy inwestycji drugiego wymiaru: obok zysku (ujętego jako oczekiwana stopa zwrotu inwestycji) o atrakcyjności inwestycji decydował również czynnik ryzyka inwestycyjnego (opisanego zmiennością stóp zwrotu). W następstwie tych odkryć zarządzający inwestycjami finansowymi zaczęli wykorzystywać dywersyfikację portfela w bardziej świadomy i tym samym efektywny sposób.

Analizy przedstawione przez Harry'ego Markowitza stały się punktem wyjścia prac Williama F. Sharpe’a nad modelem jednowskaźnikowym, który stanowił kolejny etap w rozwoju teorii portfelowej. Główną charakterystyką jego koncepcji było założenie, że stopy zwrotu z poszczególnych instrumentów finansowych powiązane są przez wspólną relację względem jednego czynnika bazowego. W swoich pracach Sharpe przedstawił kilka propozycji takiego czynnika, m.in. dynamikę wzrostu produktu krajowego brutto, war-

1 J. Lintner, The valuation of risk assets and the selection of risky investment in stock portfolios and capital budgets, „Review of Economics and Statistics” 47, 1965.

2 H. Markowitz, Portfolio selection, „Journal of Finance” 15, 1952. 
tość produkcji przemysłowej, czy zmiany wartości indeksu odzwierciedlającego zachowanie całego rynku. Kluczowe jest, aby ów czynnik był tym, który w największym stopniu determinuje stopy zwrotu z instrumentów finansowych. W przypadku rynków akcyjnych badania wykazały, że ponad 30\% przeciętnej zmienności opisuje zmienność całego rynku (stąd w praktyce model jednoczynnikowy opiera się właśnie na tej mierze). Zmienność cen całego indeksu rynku określana jest jako czynnik ryzyka systematycznego. Pozostałą część zmienności cen akcji tłumaczą (w mniej więcej podobnym udziale) czynniki dotyczące sektora gospodarki oraz informacje związane bezpośrednio z emitentem danej akcji. Czynniki te nazywane sa czynnikami ryzyka specyficznego. Wraz ze wzrostem liczby instrumentów finansowych w portfelu maleje znaczenie czynników ryzyka specyficznego, natomiast zmienność inwestycji w coraz większym stopniu wynika ze zmian o charakterze systematycznym, czyli zmian cen całego rynku. Przy kilkunastu instrumentach w portfelu jego zmienność w 90\% zależy właśnie od wahania cen szerokiego rynku ${ }^{3}$.

Podstawowa idea modelu jednowskaźnikowego, odnosząca się do powiązania stóp zwrotu przez ich relację względem pewnego czynnika stanowiła fundament kolejnego etapu rozwoju teorii portfelowej, której przedstawieniem był model wyceny dóbr kapitałowych Capital Asset Pricing Model (CAPM). Znalazł on bardzo szerokie zastosowanie w praktyce i po dziś dzień wykorzystywany jest do kalkulacji wartości kosztu kapitału własnego, badania stopnia efektywności danego rynku czy jako narzędzie do oceny efektywności inwestycyjnej funduszy inwestycyjnych.

Model wyceny dóbr kapitałowych zakłada występowanie portfela superefektywnego, czyli portfela charakteryzującego się najlepszą relacją oczekiwanej stopy zwrotu do jej zmienności. Z perspektywy problematyki zarządzania portfelem inwestycyjnym kluczowym wnioskiem płynącym z modelu jest identyfikacja portfela superefektywnego jako całego rynku akcji. Oznacza to, że żaden inny portfel o takim samym poziomie ryzyka nie oferuje wyższej stopy zwrotu ani że żaden portfel o takiej samej oczekiwanej stopie zwrotu nie okaże się mniej ryzykowny. Zatem jeśli cały rynek jest portfelem superefekywnym, niemożliwe staje się uzyskiwanie wyższych stóp zwrotu bez ponoszenia dodatkowego ryzyka inwestycyjnego.

Konkluzja ta stała się intelektualnym fundamentem budowania portfeli inwestycyjnych zarządzanych w sposób pasywny, czyli rozwiązań inwestycyjnych wiernie naśladujaccych zachowanie danego indeksu lub koszyka określonych instrumentów finansowych. W momencie gdy model wyceny dóbr kapitałowych był pierwszy raz prezentowany, możliwości inwestowania $\mathrm{w}$ portfel wiernie replikujaccy strukture całego rynku były mocno ograniczone, przede wszystkim ze względu na ograniczenia techniczne i wysokie koszty transakcyjne.

Kolejną teorią mająca znaczący wpływ na ewolucję w podejściu do zarządzania portfelem przedstawiaja dwa modele wyceny akcji zaprezentowane przez

${ }^{3}$ W.F. Sharpe, Capital asset prices: a theory market equilibrium under conditions of risk. „Journal of Finance” 19, 1964. 
Eugene'a Famę i Kennetha Frencha ${ }^{4}$ : trzyczynnikowy oraz pięcioczynnikowy. W zakresie podstawowych założeń i budowy stanowią one rozwinięcie modelu wyceny dóbr kapitałowych CAPM, który rozszerzaja przez dodanie kolejnych czynników determinujących cenę akcji. W przeprowadzonych badaniach Fama i French wykazali, że zachowanie stóp zwrotu z akcji jest w sposób istotny statystycznie zależne od mierzonej kapitalizacją wielkości danego emitenta oraz poziomu wyceny giełdowej jego akcji. Zaobserwowali oni, że mniejsze spółki charakteryzują się wyższymi przyszłymi stopami zwrotu, podobnie jak spółki o względnie niższych wartościach wskaźników wycen giełdowych (takich jak cena/zysk czy cena/wartość księgowa). Rygorystyczne testy modelu trzyczynnikowego wykazały, że w przypadku odpowiednio zdywersyfikowanych portfeli akcyjnych pozwala on wytłumaczyć $95 \%$ wartości uzyskanej stopy zwrotu.

Dalsze badania prowadzone przez Famę i Frencha ${ }^{5}$ zaowocowały odkryciem dwóch kolejnych czynników wpływających na wartość obserwowanych stóp zwrotu: rentowności danego przedsiębiorstwa oraz nakładów inwestycyjnych, co zaowocowało sformułowaniem modelu pięcioczynnikowego. Zgodnie z wynikami badań bieżąca rentowność danego przedsiębiorstwa wykazuje pozytywny wpływ na wartość przyszłych stóp zwrotu z inwestycji w akcje danej spółki. Natomiast im wyższe nakłady inwestycyjne ponoszone przez spółkę, tym niższa oczekiwana przyszła stopa zwrotu z inwestycji w akcje spółki. Rentowność przedsiębiorstwa liczona jest zwykle jako iloraz wartości wypracowanego przez spółkę zysku i wartości kapitału własnego a czynnik nakładów inwestycyjnych.

Rozwinięcie modelu trzyczynnikowego przedstawił Mark Carhart ${ }^{6} \mathrm{w}$ ramach autorskiej propozycji modelu czteroczynnikowego, który dodatkowo uwzględniał momentum. Warto zaznaczyć, że wyniki uzyskane zgodnie z modelem Carharta cechowała wyższa niż w przypadku modelu trzyczynnikowego dokładność pomiaru stóp zwrotu uzyskiwanych z portfela.

Skuteczność w objaśnianiu stóp zwrotu uzyskiwana za pomocą modeli zaproponowanych przez Famę i Frencha oraz Carharta zapoczątkowała nowy nurt w podejściu do budowy portfela inwestycyjnego i założeń dotyczących wykorzystywanej strategii inwestycyjnej, znany jako inwestowanie czynnikowe (factor investing). Głównym przedstawicielem nurtu pozostaja fundusze typu smart beta, których strategie inwestycyjne wywodzą się wprost z idei leżących u podstaw modeli Famy i Frencha.

\section{FUNDUSZE SMART BETA - OGÓLNE RAMY FUNKCJONOWANIA}

Termin „smart beta” po raz pierwszy zastosowano na początku bieżacego tysiąclecia, natomiast jego popularyzacja przypada na okres po wybuchu globalnego kryzysu finansowego. Rozumiany jest jako rodzaj strategii inwe-

\footnotetext{
${ }^{4}$ E. Fama, K. French, The three factor asset pricing model, „Journal of Finance” 47, 1992.

${ }^{5}$ Ibidem.

${ }^{6}$ M.M. Carhart, On persistence in mutual fund performance, „Journal of Finance” 52, 1997.
} 
stycyjnej zakładającej budowę portfela inwestycyjnego na podstawie indeksu skonstruowanego w sposób alternatywny ${ }^{7}$. Alternatywna konstrukcja polega na wprowadzaniu modyfikacji indeksu tradycyjnego zgodnie z przyjętymi kryteriami majacymi poprawiać efektywność inwestycji, czyli generować wyniki charakteryzujące się korzystniejszą relacją wypracowanego zysku względem ponoszonego ryzyka. Innymi słowy, chodzi o wyselekcjonowanie instrumentów o pożądanych cechach i budowę portfela zgodnie z nimi. Przyjmujac bardziej specjalistyczne ujęcie, celem ich funkcjonowania jest dostarczenie nadwyżkowej stopy zwrotu, czyli alfy z modelu CAPM ${ }^{8}$, przez umiejętne kształtowanie bety, a więc odpowiednie zarządzanie wrażliwością portfela na ogólną koniunkturę rynkową.

Fundusze powstajace na bazie tej koncepcji bardzo dynamicznie zyskują na znaczeniu. Zgodnie z danymi publikowanymi przez firmę analityczna Morningstar w ujęciu globalnym wartość aktywów pod zarządzaniem w funduszach smart beta przekroczyła w 2017 r. bilion dolarów ${ }^{9}$. Zdecydowana ich większość obejmuje strategie lokujące aktywa w ramach rynków akcyjnych, chociaż na fali rosnącej popularności pojawiają się również fundusze smart beta zaangażowane na rynkach dłużnych oraz rozwiązania zakładające dynamiczną alokację między różne klasy aktywów. Warto także wskazać, że fundusze smart beta moga charakteryzować się zarówno pasywnym, jak i aktywnym podejściem do zarządzania portfelem inwestycyjnym. Oparcie inwestycji na zarządzaniu ryzykiem systematycznym (czyli becie) w sposób bezpośredni nawiązuje do tzw. inwestowania czynnikowego (factor investing), wywodzacego się z przedstawionych wcześniej modeli wyceny Famy i Frencha oraz Carharta.

Koniec lat dziewięćdziesiątych stanowił bardzo ważny moment w historii rozwoju usług zarządzania inwestycjami z uwagi na pojawienie się pierwszych funduszy ETF (Exchange Traded Funds). Wcześniej praktycznie całość aktywów zgromadzonych w funduszach inwestycyjnych i podmiotach świadczących usługi zarządzania aktywami zaangażowana była w ramach strategii zakładających aktywne podejście do zarządzania portfelem. Fundusze ETF pozwoliły natomiast na inwestowanie w sposób mechaniczny w szeroki indeks całego rynku lub jego wybrane segmenty. Z upływem czasu w praktyce rynkowej zaczęło funkcjonować rozróżnienie na inwestowanie pasywne, czyli oparte na określonym indeksie, oraz inwestowanie aktywne, w którym decyzje w zakresie alokacji aktywów i selekcji instrumentów finansowych podejmowane są w mniej lub bardziej dyskrecjonalny sposób przez zatrudnionego zarządzającego. Pojawienie się pierwszych funduszy typu smart beta sprawiło, że dotychczasowy, ostry podział rynku stał się mniej wyraźny.

\footnotetext{
7 J. Hsu, V. Kalesnik, Finding smart beta in the factor zoo, „Research Affiliates” 14, 2015.

8 Alfa Jensena - stopa zwrotu powyżej wartości oczekiwanej wynikającej z modelu CAPM.

9 B. Johnson, A global guide to strategic beta ETPs, „Morningstar Insight” 22, 2017.
} 
Powszechnie obowiąujące klasyfikacje przyjmuja że fundusze podążające za określonym indeksem należą do grupy funduszy pasywnych. Oznacza to, że każdy fundusz ETF i każdy fundusz inwestycyjny indeksowy określane są jako fundusze pasywne, natomiast pozostała część funduszy zaliczana jest do zbioru funduszy aktywnych. W takim ujęciu fundusze smart beta zostałyby zaliczone do grupy funduszy pasywnych, co jednak nie oddaje ich faktycznego charakteru. Fundusze smart beta posiadają cechy zarówno funduszy zarządzanych w sposób aktywny, jak i cechy charakterystyczne dla rozwiązań pasywnych, pozostają przy tym oddzielną kategoria.

\section{TECHNICZNE ASPEKTY WDROŻENIA STRATEGII WYKORZYSTYWANYCH PRZEZ FUNDUSZE SMART BETA}

Badania mające na celu identyfikację kolejnych czynników, na podstawie których można by zbudować nowe strategie typu smart beta, przyniosły obfite rezultaty. Szacuje się, że w zakresie samych rynków akcyjnych w chwili obecnej wskazano już ponad 250 czynników mających wpływ na przyszłe nadwyżkowe stopy zwrotu ${ }^{10}$. Liczba robi wrażenie, niemniej wydaje się wątpliwe, aby aż tyle czynników faktycznie kształtowało zmiany cen akcji.

Takie przypuszczenie znajduje swoje potwierdzenie $\mathrm{w}$ opiniach badaczy ${ }^{11}$, którzy wskazuja, że większość odkrywanych czynników stanowi pochodna eksploracji danych (data mining), dlatego jest mało prawdopodobne, aby generowały one ponadprzeciętne stopy zwrotu w przyszłości. Mając na uwadze, że w ramach przeprowadzonych badań wykonano tysiące testów złożonych z tysięcy analiz regresji, znalezienie kolejnych czynników pozytywnie wpływających na wartość stopy zwrotu jest nieunikniona. Sytuację dobrze obrazuje prosty przykład statystyczny. Przyjmując naturalny poziom wariancji stóp zwrotu, strategia o średniej wartości ponadprzeciętnej stopy zwrotu równej 0 , przy wartości tracking error ${ }^{12}$ równej 4\%, ma mniej więcej 5-procentową szansę na pobicie benchmarku o jeden punkt procentowy w 40-letniej symulacji wstecznej. Bez przeprowadzenia bardziej wnikliwych testów przyczyn stojących za wpływem danego czynnika może się okazać, że jedna na dwadzieścia przeprowadzonych symulacji przyniesie przypadkowy, atrakcyjnie wyglądający wynik.

Powyższe wprowadzenie miało na celu nakreślenie, jak istotna jest identyfikacja faktycznych czynników kształtujących stopy zwrotu wśród tej olbrzymiej liczby przypadkowych czynników. W dalszej części artykułu zostana przedstawione najważniejsze elementy budowy strategii smart beta.

\footnotetext{
${ }^{10}$ J.L. Horowitz, T. Loughran, Three analyses of the firm size premium, „Journal of Empirical Finance" 7, 2000.

${ }^{11}$ M.in. D.H. Bailey et al., Pseudo-mathematics and financial charlatanism, „American Mathematical Society" 61(5), 2014.

${ }^{12}$ Tracking error - odchylenie standardowe stóp zwrotu z danej inwestycji i inwestycji w szeroki indeks.
} 


\section{IDENTYFIKACJA CZYNNIKÓW FAKTYCZNIE DETERMINUJĄCYCH WARTOŚCI STÓP ZWROTU}

Na potrzeby niniejszego opracowania przygotowano prosty, oparty na trzech kryteriach model, który pozwala na skuteczną weryfikację stabilności czynnika wpływającego na premię przy stopie zwrotu. W pierwszym kroku istotne jest określenie, czy dany czynnik został dogłębnie zbadany na poziomie literatury naukowej, a jego znaczenie znajduje uzasadnienie na gruncie teorii; po drugie, czy faktyczny czynnik pozwala na osiaganie ponadprzeciętnych stóp zwrotu na różnych rynkach w ujęciu geograficznym, a przy tym wykazuje trwałość i stabilność w czasie, ponadto czy działający czynnik pozostaje skuteczny niezależnie od różnego ujęcia na poziomie budowy konkretnego wskaźnika. Warto w tym miejscu nadmienić, że w literaturze funkcjonuja zaproponowane przez Christiana Harveya, Kuntary Pukhtahuanthonga i Richarda Rolla ${ }^{13}$ rygorystyczne kryteria klasyfikacji czynników o wysokim zaawansowaniu statystycznym.

Jak nakreślono wcześniej, wiele z odkrytych czynników, mających wpływ na kształtowanie się stóp zwrotu akcji, może mieć charakter zwykłej pomyłki. Potwierdzenie takiego stanu rzeczy przedstawia David H. Bailey ${ }^{14}$, który przeprowadził badania mające na celu próbę replikacji czynników przedstawionych w innych badaniach jako skuteczne. Zaskakująco duża część nie znalazła pozytywnej weryfikacji w ponownych testach. Z tego powodu bardzo istotne jest, aby czynnik został gruntowanie omówiony na łamach literatury naukowej, a jego testy przeprowadzone na podstawie kompletnych i bezbłędnych danych. Równie ważne jest teoretyczne wytłumaczenie występowania danego czynnika, czy to na gruncie teorii racjonalnych oczekiwań, czy finansów behawioralnych. Spośród najlepiej zbadanych czynników wyłonić można pięć najbardziej klasycznych. Zatem wyszukiwarka Social Science Research Network (SSRN) znajduje 2612 wyników dla czynnika wartości, blisko 600 - dla czynnika niskiej płynności oraz 480 - dla czynnika momentum. Do szeroko opisanych i gruntowanie przebadanych zaliczyć można również czynnik niskiej bety oraz czynnik niskiej zmienności.

Zdecydowana większość dotychczas prowadzonych badań dotyczyła amerykańskiego rynku akcji, zwykle przyjmowano w nich długoterminowy horyzont czasowy. Dlatego poszukując faktycznie działającego czynnika, warto zwrócić uwagę, czy znajduje on swoje potwierdzenie w badaniach dotyczacych podokresów. Przykładowo, sprawdzając wyniki uzyskane dla jednego z najlepiej udokumentowanych czynników - odnoszącego się do niskiej kapitalizacji (small cap factor) - zaobserwować można, że istotna część premii generowanej przez ten czynnik skoncentrowana jest w okresie kilkunastu miesięcy lat trzy-

${ }^{13}$ C.R. Harvey, K. Pukhtahuang, R. Roll, A protocol for factor identification, Social Science Working Paper (1431), 2014.

${ }^{14}$ D.H. Bailey et al., op. cit. 
dziestych. Co więcej, badanie przeprowadzone przez Carola R. Horowitza ${ }^{15}$ wskazuje, że od czasów odkrycia skuteczności tego czynnika (czyli połowy lat osiemdziesiątych) nie dostarczał on ponadprzeciętnych stóp zwrotu. Analogicznie należy postapić $\mathrm{w}$ przypadku weryfikacji, czy dany czynnik pozostaje skuteczny również na innych rynkach niż rynek amerykański. Jeżeli określony czynnik ryzyka lub cecha zachowania inwestorów kształtowały ceny na rynku amerykańskim, byłoby podejrzane, gdyby na innych rynkach nie wywierały wpływu. W takiej sytuacji należałoby go raczej uznać za swoisty artefakt danych niż niezawodne źródło generowania nadwyżkowych stop zwrotu.

Odnosząc się do najszerzej opisanych czynników, możemy zaobserwować, że zarówno czynnik wartości (odnoszący się do niskiego poziomu wskaźników wyceny), jak i momentum mają nawet silniejszy wpływ na rynkach poza Stanami Zjednoczonymi, co potwierdza m.in. badanie Clifforda S. Asnessa, Tobiasa J. Moskowitza i Lassego H. Pedersena ${ }^{16}$. Podobnie prace Andrei Frazziniego i Lassego H. Pedersena ${ }^{17}$ przedstawiają dowód, że spółki o niższym współczynniku beta pozwalają generować ponadprzeciętne stopy zwrotu na różnych rynkach w ujęciu geograficznym i dla różnych klas aktywów, jak również przy obraniu różnych okresów czasowych. Czynnik premii z tytułu niższej płynności znalazł z kolei potwierdzenie $\mathrm{w}$ przeprowadzonych na międzynarodowych rynkach akcyjnych badaniach Elroya Dimsona i Bernda Hankego ${ }^{18}$. Z drugiej strony przeprowadzone przez Arnotta Becka i Vitaliego Kalesnika (2014) testy czynnika niższej kapitalizacji nie pozwoliły uznać, że jego pozytywny wpływ ma szeroki, globalny charakter.

Jedna z bardziej wyczerpujących analiz persystencji danego czynnika ze względu na zmiany rynku w ujęciu geograficznym przeprowadzili Jason Hsu, Vitali Kalesnik i Vivek Viswanathan ${ }^{19}$. Test polegał na sprawdzeniu istotności statystycznej dla różnicy w wartości wskaźnika Sharpe’a pomiędzy jedna czwartą portfeli charakteryzujących się najwyższą wartością danego czynnika i jedną czwartą portfeli o najniższej wartości czynnika. Zatem jeśli dany czynnik pozwalał na wygenerowanie korzystniejszej relacji oczekiwanego zysku do potencjalnego ryzyka, to uznawano, że nie znaleziono podstaw do odrzucenia hipotezy mówiącej o istotnym jego wpływie na stopy zwrotu uzyskiwane na rynku z danego regionu.

Ostatnim z trzech elementów jest weryfikacja skuteczności danego czynnika niezależnie od zmian w sposobie jego szacowania. Przykładowo czynnik wartości standardowo ujmowany jest jako wskaźnik wyceny wartości księgowej do kapitalizacji rynkowej (book-to-market ratio). Jednakże zastapienie

15 C.R. Horowitz, T. Loughran, N.E. Savin, Three analyses of the firm size premium, „Journal of Empirical Finance" 7(2), 2000.

${ }_{16}$ C.S. Asness, T.J. Moskowitz, L.H. Pedersen, Value and momentum everywhere, „Journal of Finance" 68(3), 2013.

17 A. Frazzini, L.H. Pedersen, Betting against beta, ,,Journal of Financial Economics” 114, 2014.

18 E. Dimson i B. Hanke, The expected liquidity premium, „Review of Finance” 8, 2004.

19 J. Hsu, V. Kalesnik, V. Viswanathan, A framework for assessing factors and implementing smart beta strategies, „Journal of Index Investing” 2015, Summer. 
tej miary wskaźnikiem stopy dywidendy (dividend yield) lub stopy zysku (earnings-to-market ratio) wydaje się, że jest zabiegiem, który nie zaburzy pierwotnego znaczenia czynnika. Zatem w sytuacji, gdy dajacy pozytywne odczyty czynnik wartości, mierzony jako wartość księgowa do kapitalizacji, przestaje generować premię po jego zmianie, należy podnieść wątpliwość, czy wykazana wcześniej anomalia faktycznie występuje i czy wyniki przedstawione w ramach całego badania sa wiarygodne. W literaturze zgłaszane są propozycje, by poszczególne czynniki mierzyć jako średnią z kilku różnych wskaźników.

Tabela 1

Istotność statystyczna wpływu czynników w różnych regionach geograficznych

\begin{tabular}{|c|c|c|c|}
\hline Czynnik & Region & $\begin{array}{c}\text { Wartość } \\
\text { prawdopodobieństwa } \\
\text { testowego }\end{array}$ & $\begin{array}{c}\text { Istotność } \\
\text { statystyczna (tak/nie) }\end{array}$ \\
\hline \multirow[t]{4}{*}{ Wartości } & Stany Zjednoczone & $0,10 \%$ & Tak \\
\hline & Wielka Brytania & $3,46 \%$ & Tak \\
\hline & Europa kontynentalna & $0,07 \%$ & Tak \\
\hline & Japonia & $0,92 \%$ & Tak \\
\hline \multirow{4}{*}{$\begin{array}{l}\text { Jakości } \\
\text { emitenta }\end{array}$} & Stany Zjednoczone & $6,17 \%$ & $\mathrm{Nie}$ \\
\hline & Wielka Brytania & $4,21 \%$ & Tak \\
\hline & Europa kontynentalna & $1,95 \%$ & Tak \\
\hline & Japonia & $29,71 \%$ & $\mathrm{Nie}$ \\
\hline \multirow[t]{4}{*}{ Niskiej bety } & Stany Zjednoczone & $0,00 \%$ & Tak \\
\hline & Wielka Brytania & $0,11 \%$ & Tak \\
\hline & Europa kontynentalna & $0,02 \%$ & Tak \\
\hline & Japonia & $0,99 \%$ & Tak \\
\hline \multirow{4}{*}{$\begin{array}{l}\text { Niskiej } \\
\text { płynności }\end{array}$} & Stany Zjednoczone & $0,00 \%$ & Tak \\
\hline & Wielka Brytania & $0,94 \%$ & Tak \\
\hline & Europa kontynentalna & $4,35 \%$ & Tak \\
\hline & Japonia & $11,83 \%$ & Nie \\
\hline \multirow[t]{4}{*}{ Momentum } & Stany Zjednoczone & $0,00 \%$ & Tak \\
\hline & Wielka Brytania & $0,00 \%$ & Tak \\
\hline & Europa kontynentalna & $0,19 \%$ & Tak \\
\hline & Japonia & $28,86 \%$ & Nie \\
\hline \multirow{4}{*}{$\begin{array}{l}\text { Wielkości } \\
\text { emitenta }\end{array}$} & Stany Zjednoczone & $32,13 \%$ & Nie \\
\hline & Wielka Brytania & $58,19 \%$ & Nie \\
\hline & Europa kontynentalna & $8,64 \%$ & Nie \\
\hline & Japonia & $5,52 \%$ & $\mathrm{Nie}$ \\
\hline
\end{tabular}

Źródło: opracowanie własne na podstawie wyników badania J. Hsu, V. Kalesnik, V. Viswanathan, op. cit. 
Dotychczasowe badania stabilności generowanej premii w zależności od sposobu zdefiniowania danego czynnika nie daja jednoznacznych wyników. W zakresie konstrukcji czynnika wartości, badanie Famy i Frencha ${ }^{20}$ wykazało, że zarówno stopa zysku, jak i stopa dywidendy generują podobne rezultaty jak wskaźnik wartości księgowej do kapitalizacji. Z kolei prace Narasimhana Jegadesha i Simona Titmana ${ }^{21}$ pokazały, że czynnik momentum pozytywnie wpływa na osiaganą z inwestycji stopę zwrotu niezależnie od parametrów przyjętych dla wskaźnika siły relatywnej ${ }^{22}$. Różne miary czynnika niższej płynności dały zbieżne wyniki w opracowaniach Lawrence'a Pastora i Richarda H. Stambaugha ${ }^{23}$ oraz Yakova Amihuda ${ }^{24}$. Czynnik niższej zmienności także okazał się odporny na różne jego definicje. Z drugiej strony czynnik jakości emitenta nie wytrzymał testów Vitaliego Kalesnika i Engina Kosego ${ }^{25}$, którzy wykorzystując zblizone w konstrukcji miary rentowności spółek objętych portfelem - otrzymali zróżnicowane efekty. Jonathan B. Berk ${ }^{26}$ wykazał, że czynnik wielkości emitenta tracił swój istotny statystycznie wpływ na uzyskiwane stopy zwrotu już przy drobnych zmianach w podejściu do jego szacowania.

Podobnie jak w przypadku testu stabilności czynnika z uwagi na różne geograficznie rynki, warto także przedstawić wyniki badania przedstawionego przez Hsu, Kalesnika i Viswanathana ${ }^{27}$ w zakresie stabilności premii z czynników w zależności od różnego sposobu ich definiowania. Rezultaty ich badania zostały przedstawione w tabeli 2 . Poszczególne wartości wskazuja, że zwłaszcza czynniki wysokiej jakości emitenta oraz jego wielkości cechuje raczej niska odporność na jego różne ujęcia definicyjne.

Tabela 2

Wybrane czynniki w różnych ujęciach definicyjnych i istotność statystyczna ich wpływu na wzrost efektywności inwestycji

\begin{tabular}{|l|l|c|c|}
\hline \multirow{2}{*}{ Czynnik } & \multicolumn{1}{|c|}{ Sposób ujęcia } & $\begin{array}{c}\text { Wartość prawdo- } \\
\text { podobieństwa } \\
\text { testowego }\end{array}$ & $\begin{array}{c}\text { Istotność } \\
\text { statystyczna } \\
\text { (tak/nie) }\end{array}$ \\
\hline \multirow{3}{*}{ Wartości } & $\begin{array}{l}\text { Wartość księgowa do kapitali- } \\
\text { zacji giełdowej }\end{array}$ & $0,10 \%$ & Tak \\
\cline { 2 - 4 } & Zysk netto do kapitalizacji & $0,03 \%$ & Tak \\
\cline { 2 - 4 } & $\begin{array}{l}\text { Przepływy pieniężne do kapi- } \\
\text { talizacji }\end{array}$ & $0,04 \%$ & Tak \\
\cline { 2 - 4 } & Dywidenda do kapitalizacji & $0,05 \%$ & Tak \\
\hline
\end{tabular}

20 E. Fama, K. French, op. cit.

${ }^{21}$ N. Jegadesh, S. Titman, Momentum, „Behavioral \& Experimental Finance Journal” 24, 2011.

${ }^{22}$ Siła relatywna - liczona jako iloraz bieżącej ceny instrumentu finansowego i jego ceny z określonej liczby notowań wstecz.

${ }^{23}$ L. Pastor, R.H. Stambaugh, Liquidity risk and expected stock returns, National Bureau of Economic Research 2001.

${ }^{24}$ Y. Amihud, Illiquidity of stock returns: cross-section and time-series effects, ,,Journal of Financial Markets" 5(1), 2002.

${ }_{25}$ V. Kalesnik, E. Kose, The moneyball of quality investing, Research Affiliates 2014.

${ }_{26}$ J.B. Berk, A critique of size-related anomalies, „Review of Financial Studies” 8, 1995.

27 J. Hsu, V. Kalesnik, V. Viswanathan, op. cit. 


\begin{tabular}{|c|c|c|c|}
\hline \multirow{4}{*}{$\begin{array}{l}\text { Jakości } \\
\text { emitenta }\end{array}$} & Rentowność kapitału własnego & $6,17 \%$ & Nie \\
\hline & Rentowność operacyjna & $17,89 \%$ & Nie \\
\hline & Rentowność sprzedaży & $55,64 \%$ & Nie \\
\hline & Zadłużenie ogólne & $35,99 \%$ & Nie \\
\hline \multirow[t]{4}{*}{ Niskiej bety } & Niska beta & $0,00 \%$ & Tak \\
\hline & Niska wariancja stóp zwrotu & $0,00 \%$ & Tak \\
\hline & Niska beta (za 3 lata) & $0,00 \%$ & Tak \\
\hline & Niska wariancja (za 3 lata) & $0,00 \%$ & Tak \\
\hline \multirow{4}{*}{$\begin{array}{l}\text { Niskiej } \\
\text { płynności }\end{array}$} & 12-miesięczne obroty & $0,00 \%$ & Tak \\
\hline & 6-miesięczne obroty & $0,00 \%$ & Tak \\
\hline & 2-miesięczne obroty & $0,01 \%$ & Tak \\
\hline & Średni obrót dzienny (ADV) & $0,01 \%$ & Tak \\
\hline \multirow[t]{4}{*}{ Momentum } & $\begin{array}{l}\text { Średnia cena z dwóch miesięcy } \\
\text { względem średniej z dwunastu }\end{array}$ & $0,00 \%$ & Tak \\
\hline & $\begin{array}{l}\text { Średnia cena z dwóch miesięcy } \\
\text { względem średniej z dwunastu }\end{array}$ & $0,00 \%$ & Tak \\
\hline & $\begin{array}{l}\text { Średnia cena z dwóch miesięcy } \\
\text { względem średniej z sześciu }\end{array}$ & $0,14 \%$ & Tak \\
\hline & $\begin{array}{l}\text { Średnia cena z jednego miesią- } \\
\text { ca względem średniej z dwuna- } \\
\text { stu miesięcy }\end{array}$ & $0,01 \%$ & Tak \\
\hline \multirow[t]{2}{*}{ Wielkości } & Wartość księgowa & $32,13 \%$ & Nie \\
\hline & Suma aktywów & $41,39 \%$ & Nie \\
\hline
\end{tabular}

Źródło: opracowanie własne na podstawie wyników badania J. Hsu, V. Kalesnik, V. Viswanathan, op. cit.

\section{WDROŻENIE CZYNNIKA W PRAKTYCE}

Badania przedstawiające istotny wpływ określonego czynnika na stopę zwrotu z inwestycji zwykle nie uwzględniają praktycznych aspektów inwestowania na rynkach finansowych. Większość pozytywnych wyników uzyskiwana jest na podstawie symulacji wstecznych przygotowanych portfeli, co wiąże się z pominięciem kosztów transakcji, ale również kwestii opłat pobieranych na poziomie danego funduszu $\mathrm{z}$ tytułu zarządzania. $\mathrm{O}$ ile ich zignorowanie jest zrozumiałe z punktu widzenia badań naukowych, mających na celu odkrycie czynnika pozwalającego generować nadwyżkowy zwrot, o tyle w realiach rynkowych mogą one pochłonąć całą premię związaną z danym czynnikiem.

Warto mieć przy tym na uwadze, że stawki opłat za zarządzanie w funduszach typu smart beta kształtuja się na poziomie zbliżonym do przeciętnych wartości odpowiednich dla funduszy indeksowych. Badanie Tylera Shumwaya i Victora A. Warthera ${ }^{28}$ wykazało, że próby wdrożenia podejścia czynnikowego

${ }_{28}$ T. Shumway, V.A. Warther, The delisting bias in CRSPs Nasdaq data and its implications for the size effect, „Journal of Finance” 54, 1999. 
w ramach portfeli zarządzanych w sposób aktywny (w przypadku koncentracji na rynkach akcyjnych, wiążących się z opłatami za zarządzanie na poziomie często powyżej dwóch procent w skali roku) premia wynikająca z czynników nie pozwala rekompensować utraty wartości portfela, wynikającej z pobieranych opłat z tytułu zarządzania. Stąd skuteczność podejścia czynnikowego uzależniona jest od obrania bardziej mechanistycznych metod zarządzania portfelem inwestycyjnym (np. fundusze indeksowe).

Natomiast element kosztów transakcyjnych jest istotnym problemem implementacyjnym. Zgodnie z rezultatami uzyskanymi przez Roberta Novy'ego-Marxa i Maximiliana Velikova ${ }^{29}$ w przypadku portfeli generujacych wysokie poziomy obrotu szacowane miesięczne koszty transakcyjne moga wynieść od 20 do nawet 57 punktów bazowych (liczonych od wartości aktywów zarządzanych w ramach portfela) w ujęciu miesięcznym. Spośród najpopularniejszych czynników wysokie koszty transakcyjne dotyczą zwłaszcza momentum i niskiej płynności, stąd ich zastosowanie wymaga zaprojektowania odpowiedniej taktyki transakcyjnej. W odniesieniu do strategii smart beta zarządzanych w sposób pasywny i bazujących na czynnikach charakteryzujacych się wysoką częstotliwością zawierania transakcji wskazać można również pewien interesujący efekt uboczny. Z uwagi na dużą transparentność strategii oraz jej ścisłe, formalne ramy realizowania (określone na poziomie budowy indeksu będącego punktem odniesienia struktury portfela), fundusze tego typu stają się zaproszeniem dla inwestorów praktykujących tzw. front-running ${ }^{30}$. W efekcie zawyżone zostają ceny instrumentów finansowych objętych indeksem i tym samym premia generowana przez czynnik ulega redukcji. Wydaje się, że strategie oparte na czynnikach niskiej płynności i momentum najlepsze efekty przynosić będą w portfelach zarządzanych aktywnie przez podmioty o ponadprzeciętnych umiejętnościach zawierania transakcji, charakteryzujące się ponadto umiarkowanymi opłatami za zarządzanie i o wysokiej dyscyplinie.

\section{KONSTRUKCJA INDEKSU SMART BETA}

Wdrożenie strategii czynnikowej wymaga podjęcia decyzji dotyczącej wyboru pomiędzy aktywnym lub pasywnym podejściem do zarządzania portfelem inwestycyjnym. Przyjmując zarządzanie pasywne, kluczowy staje się sposób implementacji określonych czynników w ramach strategii, objawiający się ustaleniem zestawu założeń dotyczących budowy indeksu. W przypadku strategii opartych na czynniku wartości optymalizacja składu portfela względem

${ }^{29}$ R. Novy-Marx, M. Velikov, A taxonomy of anomalies and their trading costs, National Bureau of Economic Research 2014.

${ }^{30}$ Front Running - zjawisko polegające na zawieraniu transakcji wyprzedzających spodziewaną transakcję dotyczących tego samego instrumentu finansowego zawieraną przez inwestora instytucjonalnego. Celem takiego zachowania jest wykorzystanie wzrostu (spadku) cen wywołanego skalą transakcji zawartej przez inwestora instytucjonalnego. 
maksymalizacji oczekiwanej wartości premii może skutkować niedostatecznym poziomem płynności. W konsekwencji po przekroczeniu pewnej wartości aktywów pod zarządzaniem strategia może przestać generować spodziewana premię. W związku z tym istotne jest, aby wartość zgromadzonych w funduszu aktywów była w odpowiedni sposób dopasowana względem wartości akcji pozostających w obiegu poszczególnych pozycji w portfelu.

Skonstruowany na potrzeby funduszu smart beta indeks powinien również uwzględniać kwestię częstotliwości dostosowywania struktury portfela. Przy czym powinna ona być ściśle uzależniona od obranego czynnika, który determinuje okres niezbędny do uchwycenia premii. Przykładowo dla strategii opartej na momentum wymaga się zwykle comiesięcznego dostosowania składu indeksu. Jeżeli operację wykonuje się rzadziej, to premia może nie być uchwycona w całości. Z kolei dla strategii zbudowanej na czynniku wartości zakłada się, że optymalny okres dostosowania składu portfela wynosi około jednego roku. Warto zaznaczyć, że większa częstotliwość zmian w portfelu prowadzić będzie do wzrostu kosztów transakcyjnych, natomiast nie poprawi wartości wygenerowanej premii. Zatem z perspektywy skuteczności, inaczej strategii smart beta, dopasowanie okresu rewizji składu portfela względem czynnika premii stanowi element krytyczny, głównie ze względu na wartość ponoszonych kosztów transakcyjnych.

W zakresie problematyki zarządzania kosztami transakcyjnymi interesujace koncepcje przedstawił w swoich pracach David Blitz ${ }^{31}$. Jedna z nich jest szczególnie warta krótkiego przedstawienia. Technika ta została określona jako staggered rebalancing (w wolnym tłumaczeniu: dostosowanie składu portfela rozłożone w czasie) i odnosi się do portfeli zarządzanych pasywnie realizujących strategie oparte na jednym lub więcej czynnikach. Podstawowym jej założeniem jest podział portfela na kilka transz, spośród których każda posiada przypisaną jej optymalną dla danego czynnika częstotliwość, ale terminy dostosowywania składów portfeli są dla poszczególnych czynników różne. Przykładem obrazującym działanie tej metody może być portfel zbudowany na czynniku wartości. Jego aktywa zostaja podzielone na cztery kwartalne transze o okresie dostosowania składu jednego roku każda. W konsekwencji dostosowanie składu portfela dokonywane jest przy kwartalnym interwale, co skutecznie pozwala wyraźnie zredukować wpływ wynikający z zawieranych transakcji na ceny akcji. Przedstawiona koncepcja podziału na transze kwartalne może być równie dobrze przeniesiona na grunt transz miesięcznych w przypadku wyjątkowo dużych portfeli. Należy przy tym pamiętać, że w przypadku zarządzania kosztami transakcyjnymi niezwykle istotne pozostają umiejętności w zakresie realizacji zleceń na rynku. Odpowiednio zarządzany proces transakcyjny nie tylko minimalizuje wpływ zawieranych transakcji na ceny rynkowe, ale może stanowić źródło dodatkowej stopy zwrotu przez umiejętne uchwycenie różnicy w cenach między zleceniami kupna i sprzedaży.

31 D. Blitz, B. van der Grient, P. van Vliet, Fundamental indexation: rebalancing assumptions and performance, ,The Journal of Index Investing” 1(2), 2010. 


\section{BUDOWA STRATEGII OPARTEJ NA KILKU CZYNNIKACH}

Znacząca część funduszy smart beta opiera swoją strategię inwestycyjna na pojedynczym czynniku premii, jednakże wraz z rozwojem tego segmentu coraz częściej spotykane są fundusze bazujące na złożeniu kilku czynników w ramach jednej strategii. Niniejsza część artykułu zostanie poświęcona aspektom budowy strategii opartej na kilku czynnikach.

Po zidentyfikowaniu zestawu czynników generujących premie i odpowiednim opracowaniu sposobu efektywnej implementacji każdego z nich w ramach określonej strategii pozostaje przyjęcie mechanizmu alokacji określonych części portfela między poszczególne czynniki. Sama alokacja powinna być determinowana przede wszystkim założonym poziomem ryzyka całego portfela. Przy czym należy mieć na uwadze, że ryzyko to może przyjmować różne ujęcia. W przypadku tego typu strategii wyróżnia się ryzyko bezwzględne (mierzone poziomem zmienności wartości inwestycji) oraz ryzyko względem obranego indeksu odniesienia (mierzone za pomoca tracking error). Istotność takiego rozróżnienia zostanie zilustrowana za pomocą prostego przykładu. Aby uzyskać możliwie niski poziom zmienności portfela, zarządzający funduszem smart beta może znaczącą część aktywów portfela alokować w ramach strategii opartej na czynniku niskiej zmienności. W ogólnym założeniu taka decyzja może wydawać się jak najbardziej słuszna: omawiana strategia powinna zapewnić podobną lub nawet wyższą niż rynkowa stopę zwrotu przy niższych wahaniach wartości portfela. Trzeba mieć jednak na uwadze, że efektem ubocznym niższej zmienności (a więc ryzyka bezwzględnego) będzie wyższa wartość tracking error. Rozważmy pewien scenariusz. Zakładając okres wyjątkowo dobrej koniunktury, przyjmijmy, że indeks szerokiego rynku (a więc odzwierciedlający zachowanie wszystkich akcji) zyskiwał $20 \%$ każdego roku przez pięć lat. Wyniki badań wskazuja, że strategie oparte na czynniku niskiej zmienności charakteryzują się współczynnikiem beta przeciętnie na poziomie 0,7 przy tracking error przekraczającym $10 \% \mathrm{w}$ skali roku ${ }^{32}$. W rozpatrywanym przykładzie oznaczałoby to roczną stopę zwrotu z inwestycji niższą o 6 , a nawet 10 punktów procentowych. Chociaż przedstawiony scenariusz był skrajnie optymistyczny, to jednak wskazuje na potencjalną skalę kosztów alternatywnych ponoszonych z powodu zbyt dużego zaangażowania aktywów funduszu w ramach jednej strategii.

$\mathrm{W}$ przypadku zagadnienia alokacji portfela w ramach różnych klas aktywów bardzo dużą rolę odgrywa analiza oczekiwanych stóp zwrotu i ich zmienności, a także korelacji pomiędzy poszczególnymi instrumentami. Wskazane wyżej elementy stanowią również istotną część analizy prowadzonej przy określaniu alokacji aktywów między wybrane czynniki, niekoniecznie jednak wystarczą do dokonania jej w sposób efektywny. DeMiguel ${ }^{33}$ wykazał, że portfele optymalizowane względem relacji zrealizowanej stopy zwrotu i historycznej wariancji osiagają gorsze wyniki niż portfele, w przypadku których zastosowa-

${ }^{32}$ J.H. Cochrane, Presidential address: discount rates, „Journal of Finance” 66, 2011.

${ }^{33}$ V. DeMiguel, L. Garlappi, The moneyball of quality investing, Research Affiliates 2006. 
no naiwne podejście nadające równe wagi wszystkim akcjom z indeksu. Główne wyzwanie we wdrażaniu tradycyjnej optymalizacji w ramach współczesnego podejścia do alokacji portfela stanowi fakt, iż oczekiwane stopy zwrotu i ich korelacje wykazują tendencję do niestabilności w czasie. Co więcej, często obserwowane jest zjawisko ich powrotu do średniej. Zgodnie z rezultatami uzyskanymi przez Randolpha Cohena ${ }^{34}$ premia wynikajacca z czynnika wartości wykazuje tendencje do znacznych wahań w czasie, a jej szacowanie jest silnie obciążone niedawnymi obserwacjami, co może istotnie zaburzać wyniki.

Warto mieć jednak na uwadze, że wraz z rozwojem badań w zakresie finansów rośnie poziom świadomości w zakresie współzależności pomiędzy zmiennymi i ich wpływu na kształtowanie premii, co powinno wspierać jakość szacowania oczekiwanych stóp zwrotu i parametry ryzyka dla poszczególnych czynników. Przykładowo, badanie Kennetha D. Daniela i Tobiasa J. Moskowitza $^{35}$ wykazało, że premia związana z czynnikiem momentum istotnie wzrasta w warunkach podwyższonej zmienności rynkowej.

\section{PODSUMOWANIE}

Niniejszy artykuł miał na celu poruszenie kilku wybranych aspektów funkcjonowania funduszy inwestycyjnych określanych jako smart beta, będących hybrydą aktywnego i pasywnego podejścia do zarządzania portfelem inwestycyjnym. Samo oparcie strategii na inwestowaniu czynnikowym stanowi bezpośrednie nawiązanie do koncepcji, na których bazują modele Famy i Frencha czy Carharta.

Poza przeglądową prezentacją koncepcji teoretycznych stanowiących podstawę działania funduszy smart beta oraz nakreśleniem ich ogólnej istoty głównym zagadnieniem poruszonym w artykule jest kwestia skutecznego doboru czynników do budowy strategii wykorzystywanych przez fundusze smart beta. W tym zakresie przedstawiono trzystopniowy model pozwalajacy na efektywną selekcję czynników generujących stabilną premię przy stopie zwrotu. Identyfikacja faktycznie działajacych czynników jest szczególnie istotna z perspektywy stopniowego zanikania efektu związanego z tymi już wcześniej zidentyfikowanymi.

Fundusze smart beta stanowią atrakcyjny przedmiot badawczy ze względu na oparcie procesu inwestycyjnego na bieżących osiagnięciach naukowych oraz zaawansowanych rozwiąaniach technologicznych. Jak przedstawiono w toku artykułu, fundament koncepcji funduszy smart beta wywodzi się wprost z modeli wyceny aktywów kapitałowych, a ich strategie inwestycyjne bazują bezpośrednio na wynikach badań naukowych. Sam proces zarządzania portfelem takiego funduszu jest natomiast wysoce zautomatyzowany i odbywa się praktycznie bez udziału człowieka. W konsekwencji fundusze smart beta

${ }_{34}$ R.B. Cohen, C. Polk, T. Vuolteenaho, The value spread, „Journal of Finance” 38, 2003.

35 K.D. Daniel, T.J. Moskowitz, Momentum crashes, „Review of Finance” 7, 2013. 
cechuje transparentna polityka inwestycyjna i niski poziom kosztów po stronie inwestora.

Warto zaznaczyć, że fundusze smart beta sa bardzo młodym segmentem sektora instytucji wspólnego inwestowania, ale już zdążyły wypracować sobie ważna pozycję w jego ramach. Na rynku polskim ich popularność pozostaje jednak niska i niewielu inwestorów instytucjonalnych deklaruje alokację w ramach tego typu rozwiązań ${ }^{36}$. Również patrząc z perspektywy opracowań o charakterze naukowym, fundusze smart beta pozostaja praktycznie niezbadane. Wydaje się jednak, że w najbliższych latach obserwowany będzie wzrost napływów do tego typu rozwiązań. Biorąc pod uwagę charakterystykę tego typu rozwiąań inwestycyjnych, mogą one stanowić interesująca alternatywę dla drogich i przeciętnie efektywnych tradycyjnych funduszy inwestycyjnych zarządzanych w sposób aktywny. Taki rozwój sytuacji stworzyłby interesujące możliwości prowadzenia badań funduszy smart beta na podstawie obserwacji rodzimego rynku.

mgr Albert Trapczyński

Uniwersytet Ekonomiczny w Poznaniu

albert.trapczynski@ue.poznan.pl

\section{SMART BETA FUNDS - PASSIVE AND EFFECTIVE PORTFOLIO MANAGEMENT}

\section{Summary}

As a result of the technological development and the emergence of new theoretical concepts of investment funds strategies, a new category of funds, known as smart beta, has emerged. The foundation of their functioning assumes constructing an investment portfolio that replicates a specially developed index, the design of which is to ensure a higher investment efficiency than that resulting from a typically passive investment. With the task of combining the ability to generate premium rates of return with a transparent structure and low management fees, smart beta funds are a very interesting hybrid of classical actively and passively managed funds. The interest of researchers and investors in these funds has been so far limited mainly to the United States. In the case of the Polish market - smart beta funds continue to remain a concept that is not widely known. This fact has become a prerequisite for disseminating knowledge about them in the Polish literature of the subject. The first part of the article presents the theoretical framework of smart beta funds as a consequence of a long-term evolution in portfolio management. Next, the general idea of the functioning of the smart beta funds is presented together with the outline of their place in the structure of the financial market segment. The main and the most extensive part of the article is based on literature studies and aims at an in-depth review of the key technical aspects related to the construction of an effective strategy used by smart beta funds.

${ }^{36}$ Smart Beta: 2017 Global survey findings from asset owners, FTSE Russell, 2017. 